\title{
Erratum to: Biosynthesis of phenolic compounds in Vitis vinifera cell suspension cultures: Study on Hydroxycinnamoyl CoA: ligase
}

Samia Lotfy • Annie Fleuriet - Teresa Ramos •

Jean-Jacques Macheix

Published online: 21 February 2014

(c) Springer-Verlag Berlin Heidelberg 2014

Erratum to: Plant Cell Reports (1989) 8:93-96

DOI 10.1007/BF00716847

In the original publication, the author's name has been misspelt as Samia Lofty instead of Samia Lotfy. It has been corrected in this erratum.

The online version of the original article can be found under doi:10.1007/BF00716847.

S. Lotfy $(\bowtie)$ - A. Fleuriet · T. Ramos · J.-J. Macheix Laboratoire de Physiologic Végétale Appliquée,

Université des Sciences et Techniques du Languedoc,

F 34060 Montpellier Cedex, France

e-mail: samilotfy@yahoo.fr 